\title{
Diagnosis of the availability and use of drug information sources in drugstores and pharmacies in southern Brazil
}

\author{
Fabiana Wahl Hennigen ${ }^{1 *}$, Maria Isabel Fischer ${ }^{2}$, Aline Lins Camargo ${ }^{3}$, Isabela Heineck ${ }^{4}$ \\ ${ }^{1}$ Faculty of Pharmacy, Federal University of Rio Grande do Sul (UFRGS), ${ }^{2}$ Medicines Information Center of Rio Grande do \\ Sul (CIM-RS), ${ }^{3}$ Department of Biomedical Sciences, Center of Biological and Health Sciences, University of Caxias do Sul \\ (UCS), ${ }^{4}$ Department of Medicines Production and Control, Faculty of Pharmaceutics, UFRGS
}

\begin{abstract}
This research has aimed to estimate the use of drug information sources by pharmacists in drugstores and pharmacies in southern Brazil. It consisted of sending a questionnaire through regular mail, contacting the pharmacist via phone and visiting the drugstores. Four hundred and eight (68.6\%) of the 595 enrolled establishments answered the questionnaire. The information at pharmacies and drugstores is searched mainly to orient the patient. At drugstores the professionals have an average of 2.3 books, whereas at pharmacies they rely on 6.1. In a pharmacy, the chance to find more than five books is 27 times higher than in a drugstore. The more often available books are pharmaceutical specialties compendiums. There is access to Internet in $87.5 \%$ of pharmacies and $59 \%$ of drugstores. The National Agency of Health Surveillance webpage is the most accessed website, and the call centers of Pharmaceutical Companies are the most searched information service. Lack of time is the main alleged difficulty for searching information. The pharmacists working in the studied establishments miss appropriate drug information sources. Taking into consideration how important information is in the pharmaceutical practice, there is a need to emphasize this subject through an educative process, during undergraduate studies and continued education.
\end{abstract}

Uniterms: Pharmaceutical assistance. Drugs/information availability. Pharmaceutical practice.

A pesquisa teve como objetivo descrever a utilização de fontes de informação em drogarias e farmácias no sul do Brasil. A mesma consistiu do envio do questionário pelo correio, contato com farmacêuticos por telefone e visita aos estabelecimentos. A resposta foi obtida em $408(68,6 \%)$ dos 595 estabelecimentos amostrados. A informação nas farmácias e drogarias é buscada, principalmente, para orientar o paciente. O profissional tem, em média, 2,3 livros nas drogarias e 6,1 nas farmácias. Em uma farmácia, a chance de se encontrar mais de cinco livros corresponde a 27 vezes aquela em uma drogaria. Os bulários são os livros mais freqüentemente disponíveis. Há acesso à Internet em 87,5\% das farmácias e em 59\% das drogarias, sendo a chance de uma farmácia ter este recurso, cinco vezes maior que aquela em uma drogaria. A página da Agência Nacional de Vigilância Sanitária é a mais acessada e o Serviço de Atendimento ao Consumidor das Companhias Farmacêuticas, o serviço de informação mais consultado. A falta de tempo é a principal limitação da busca de informação. O farmacêutico nos estabelecimentos pesquisados é carente de fontes adequadas de informação. Considerando a importância da informação na prática farmacêutica, é necessário enfatizar o tema utilizando um processo educativo no período de formação e em atividades de atualização.

Unitermos: Assistência farmacêutica. Medicamentos/disponibilidade de informação. Prática farmacêutica.

\section{INTRODUCTION}

The use of medicines has been motive of worry to society. It is estimated that between one third and a half of

*Correspondence: F. W. Hennigen. Centro de Informações sobre Medicamentos do Rio Grande do Sul (CIM-RS). Av. Ipiranga, $2752-2^{\circ}$ Andar - sala 203 - 90610-000 - Porto Alegre -RS, Brasil. E-mail: fabiwh@yahoo.com medicines used all over the world are wasted, with impacts on economy and health (Vidotti, 2004).

Medicines occupies an important role in the health system and, when appropriately utilized, it is the most frequently cost-effective therapeutic resource. However, situations such as products low quality, prescription mistakes and lack of patient orientation respecting to treat- 
ment, could conduct to medication irrational use. Adverse effects, limited efficacy and pharmacodependence are some of the consequences of this irrational use (Marin et al., 2003).

The introduction of new medications and the advancement in the knowledge respecting the already utilized ones has been accompanied by an increase in the quantity and complexity of information (Amerson, Gora-Harper, 2001). The availability of updated and independent sources of technical-scientific information, as well as their appropriate utilization, are indispensable requisites to assure the rational use of medications (OPAS, 1995).

In Brazil, the information is not easily available yet, and the majority of undergraduate courses do not enable pharmacists for its management. The movement for a conduct change from pharmacists, to become co-responsible for therapy safety and efficacy, is relatively recent and could reverse the perceived dissociation between the economic and health interests, which has contributed for the characterization of drugstores and pharmacies as commercial establishments detached from the process of healthcare (Ivama et al., 2002). The frequent absence of a pharmacist in these establishments reveals the nonaccomplishment of Brazilian Health Legislation (Brasil, 1973), and creates the opportunity to outsiders assuming the professional's attributions, enabling the irrational use of medications.

In the literature, there are studies respecting the utilization of information sources of pharmacists, mainly at Medications Information Centers (Centros de Informação sobre Medicamentos - CIM) (Müllerová, Vlcek, 1998; Rosenberg et al., 2004). However, fill studies approach the utilization of such sources by professionals acting in drugstores and pharmacies. In Brazil, there is a lack of these studies.

This present study has as purpose to describe the availability of information sources about medications, including books, Internet and information services, and their utilization by pharmacists acting in drugstores and pharmacies, in the Metropolitan Region of Porto Alegre.

\section{METHOD}

The research followed the model of transversal study and was developed from 2006 March to July. It consisted of the questionnaire sending by regular mail, phone contact with professionals and visit to pharmacies and drugstores. In the 31 municipalities of the Metropolitan Region of Porto Alegre, until 2005 June, 984 (74.4\%) drugstores and 338 (25.6\%) pharmacies were regularly registered at the Regional Council of Pharmaceutics of Rio
Grande do Sul (Conselho Regional de Farmácia do Rio Grande do Sul-CRF-RS), totalizing 1322 establishments (METROPLAN, 2005).

\section{Sample description}

The sample size calculation allowing a comparison of diverse aspects related to information sources in the two types of establishment, has taken into account a proportion of $50 \%$ for the variables, an error margin of $5 \%$ and a confidence level of $95 \%$. It was obtained a sample of 277 drugstores and 180 pharmacies, totalizing 457 establishments.

A pilot study was developed sending the questionnaire by regular mail, as a response-letter, to 50 randomly selected establishments, by lottery. Considering the study results, which obtained losses around 30\%, this percentage was added to initial sample values, resulting in 595 establishments, being 361 drugstores and 234 pharmacies.

The sample selection was developed by means of randomly sampling stratified by establishment type. Drugstores and pharmacies placed at Metropolitan Region of Porto Alegre and regularly registered at the CRF-RS were included in the research. The establishments exerting both activities (as pharmacy and drugstore) were considered as pharmacies, once they are so registered at CRF-RS.

The questionnaires not answered in a complete and understandable way (at least 25 of 34 questions) were excluded from the study, always as the respective pharmacist did not agree to complete or clarify the questions. In the situations in which more than a questionnaire was answered by a single establishment, it was considered only the first received one.

\section{Data collection}

The questionnaire was sent to establishments by response-letter, communicating to pharmacist the options for response: letter, fax or Internet. The phone contact started a week after the material sending, emphasizing the importance of study and the options for response. For every establishment were developed, as a maximum, two attempts of contact with the pharmacist. Finalized the phone contacts, two visits were done to establishments whose pharmacists had not answered the questionnaire.

The data collection instrument was developed from the questionnaire elaborated by other authors in a similar research developed in Switzerland (Zehnder, 2004). The first version was tested and adequate, being the final one composed by 34 questions, approaching the following topics: 
- Medicines information sources: used sources (books, Internet and information services), place of access, type of information, frequency of use and finality of search;

- Establishment: type of establishment and number of pharmacists;

- Professional: owner/employee, exerted activities, gender, age, place and year of graduation.

\section{Data organization and analysis}

The databank was developed in the software Epi Data. The transference of responses was executed twice, by different and independent typists. The databanks were compared and the discrepancies were corrected.

The statistical analysis, descriptive and comparative, was developed utilizing the software Epi Info 6.0 and SPSS 13.0. For the comparative analysis, odds ratio, $U$ tests of Mann-Whitney and chi-square were utilized, to evaluate the statistical significance between the averages and proportions, respectively, considering a $P$-value lower than 0.05 .

\section{Ethical aspects}

The research project was approved by the Committee of Ethics in Research of Federal University of Rio Grande do Sul.

\section{RESULTS}

\section{Response to questionnaire}

The response to questionnaire was obtained in 408 (68.6\%) of the 595 establishments of sample. The absence of the pharmacist in the establishment was the most fre- quent motive for non-response (12.6\%) (Figure 1). The majority of questionnaires were obtained by means of a place visit (55.9\%). From among the suggested return proposals, the response-letter $(23 \%)$ was the most utilized. After the sending of correspondence and the phone contact, the visit was developed to $410(68.9 \%)$ establishments. In the evaluation of the following presented results, it should be considered that some participants did not respond the totality of questionnaire questions, in this way, the total of 408 is not valid for all variables.

\section{Establishment}

The 408 establishments participating of study are distributed in 29 municipalities of Metropolitan Region of Porto Alegre. According to their developed activities, $54.5 \%$ of establishments are classified as drugstore, $29.7 \%$ as pharmacy and $15.7 \%$ as drugstore and pharmacy.

There are one to six pharmacists per establishment, but the majority counts on a single professional (238$60.4 \%$ ). The pharmacies count on a higher number of professionals as compared to drugstores (Table I).

\section{Professional}

The pharmacists are between 21 and 76 years old, being the mean age $34.7 \pm 10.4$ years and the range up to 30 years is the prevalent one $(194-48 \%)$. The majority pertains to female gender $(321-78.7 \%)$. The professionals acting in 49.5\% (199) of establishments are from public universities. The responders completed their undergraduate courses $10.1 \pm 9.8$ years ago, as an average, but the majority from $2000(198-50.6 \%)$ upward. Respecting to establishment ownership, pharmacies belong more to pharmacists than drugstores (Table I).

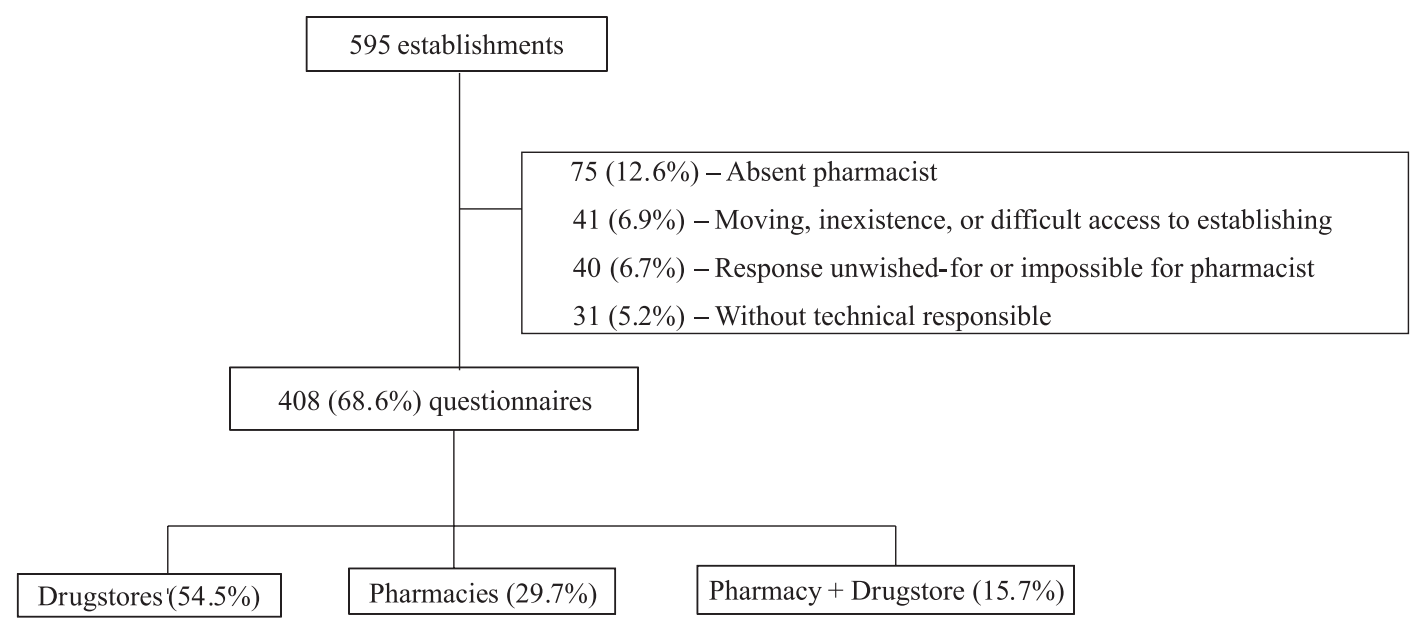

FIGURE 1 - Graphic schematization of adhesion index of establishments to research 
TABLE I - Relationship between drugstores and pharmacies respecting to number of pharmacists, ownership of establishment and information sources

\begin{tabular}{|c|c|c|c|c|}
\hline & $\begin{array}{c}\text { Drugstore } \\
\text { N (\%) }\end{array}$ & $\begin{array}{c}\text { Pharmacy } \\
\text { N (\%) }\end{array}$ & $\begin{array}{l}\text { OR } \\
\text { (IC) }\end{array}$ & $P$ \\
\hline \multicolumn{5}{|c|}{ Pharmacist } \\
\hline 1 & $146(68.6)$ & $92(51.1)$ & --- & --- \\
\hline$>1$ & $67(31.4)$ & $88(48.9)$ & $2.1(1.4-3.2)$ & 0.000 \\
\hline \multicolumn{5}{|c|}{ Owner pharmacist } \\
\hline Yes & $41(18.5)$ & $101(54.6)$ & $5.3(3.3-8.5)$ & 0.000 \\
\hline No & $181(81.5)$ & $84(45.4)$ & --- & --- \\
\hline \multicolumn{5}{|c|}{ Number of books } \\
\hline $0-5$ & $211(95)$ & $76(41.5)$ & --- & --- \\
\hline$>5$ & $11(5)$ & $107(58.5)$ & $27(13.2-56.7)$ & 0.000 \\
\hline \multicolumn{5}{|c|}{ Internet access } \\
\hline Yes & $131(59)$ & $161(87.5)$ & $4.9(2.8-8.4)$ & 0.000 \\
\hline No & $91(41)$ & $23(12.5)$ & --- & --- \\
\hline
\end{tabular}

$\mathrm{OR}=$ odds ratio; $\mathrm{IC}=$ interval of confidence (considering $\mathrm{p}<0.05$ )

Respecting to exerted activities, the dispensation was the most mentioned at first option $(159-39.2 \%)$, followed by management activities and general supervision $(132-32.5 \%)$. The pharmacists mentioned to search for information, mainly, to orient the patient respecting to use indications, pharmacology and administration/mode of use (Table II).

TABLE II - Main types of information searched in books and Internet

\begin{tabular}{|c|c|c|}
\hline \multirow[t]{3}{*}{ Type of information } & \multicolumn{2}{|c|}{ Response as $1^{\text {st }}, 2^{\text {nd }}$ or $3^{\text {rd }}$ option } \\
\hline & Books & Internet \\
\hline & $\mathbf{N}(\%)$ & $\mathbf{N}(\%)$ \\
\hline Indications of use & $221(55.8)$ & $200(52.1)$ \\
\hline Pharmacology & $164(41.4)$ & $148(38.5)$ \\
\hline Administration/mode of use & $160(40.4)$ & $119(31.0)$ \\
\hline Interactions & $138(34.8)$ & $108(28.1)$ \\
\hline
\end{tabular}

\section{Information sources about medicines}

\section{Books and Internet}

There is not an available book for the search of information about medicines in $6.9 \%$ (28) of analyzed establishments. In the drugstores, the professional counts on $2.3 \pm 1.6$ books as an average, while in the pharmacies they have $6.1 \pm 3.2$. In a pharmacy, the chance to find more than five books is 27 times larger as that in a drugstore (Table I). The majority of pharmacists utilizes daily the available books $(231-61.6 \%)$, being $2.3 \pm 12.7$ the average of consultations per day. The predominance was of national publications, mainly pharmaceutical specialties compendiums, such as the Dictionary of Pharmaceutical Specialties (Dicionário de Especialidades Farmacêuticas - DEF), whose utilization is complemented by the Guanabara Therapeutic Dictionary (Dicionário Terapêutico Guanabara), which presents concise monographs respecting the therapeutic use of drugs (Table III). Evaluating the updating of mentioned books, it was verified that the minority corresponds to the most recent available edition. Only in $19.9 \%$ (81) of establishments is found the most recent edition of DEF.

There is Internet access in $87.5 \%$ (161) of pharmacies and 59\% (131) of drugstores (Table I). In the majority of establishments, Internet is used weekly $(170-46.1 \%)$, being $6.4 \pm 1.4$ the average of consultations per week. Every professional consults, as an average, $2.6 \pm 1.7$ sites.

The homepage of the National Agency of Health Surveillance (Agência Nacional de Vigilância Sanitária - ANVISA), the more accessed one, is consulted by professionals of $52.3 \%$ (191) of establishments. The search websites and the electronic pages of professional entities, such as Councils of Pharmaceutics, are frequently utilized. The MEDLINE/PubMed was the more mentioned database for articles localization (Table III).

\section{Information Services}

The Consumer Attendance Service (CAS) of pharmaceutical distributors and industries was already utilized 
TABLE III - Availability and utilization of information sources

\begin{tabular}{lc}
\hline Book title & N (\%) \\
$\begin{array}{l}\text { Dictionary of Pharmaceutical Specialties } \\
\text { (DEF) }\end{array}$ & $277(68.2)$ \\
$\begin{array}{l}\text { Guanabara Therapeutic Dictionary } \\
\text { (Korolkovas) }\end{array}$ & $129(31.8)$ \\
Brazilian Pharmacopeia & $127(31.3)$ \\
$\begin{array}{l}\text { P.R. Vade-mécum (packages inserts } \\
\text { compilations) }\end{array}$ & $106(26.1)$ \\
Martindale's The Extra Pharmacopoea & $73(18.0)$ \\
Website & \\
ANVISA & $191(52.3)$ \\
Search websites & $177(48.5)$ \\
CRF-RS & $123(33.7)$ \\
Pharmaceutical Industries/Distributors & $120(32.9)$ \\
MEDLINE/Pubmed & $31(8.5)$ \\
Information service & \\
Consumer Attendance Service (CAS) & $222(56.1)$ \\
Medications Information Center of Rio Grande & $151(37.7)$ \\
do Sul (CIM-RS) & \\
Center of Toxicological Information- Rio \\
$\begin{array}{l}\text { Grande do Sul (CIT-RS) } \\
\text { Service of Information about Teratogenic } \\
\text { Agents (SIAT) } \\
\text { Live voice }\end{array}$ \\
\hline
\end{tabular}

by the pharmacists of $56.1 \%$ (222) of establishments, being the most consulted service (Table III). The majority of users $(101-45.5 \%)$ utilizes it monthly. The service is utilized, mainly, to obtain information respecting products availability in the market $(81-20.7 \%)$ and to notify quality deviations or adverse reactions $(46-11.7 \%)$.

The pharmacists of $37.7 \%$ (151) of establishments mentioned to have already consulted the CIM-RS (Table III). Out of the Center users, $48.3 \%$ (73) consult it yearly.

The local Center of Toxicological Information (Centro de Informação Toxicológica - CIT-RS) was already utilized by $37.2 \%$ (152) of responders. The Center that gives information about teratogenic agents (SIAT) and the Live Voice, a telephonic central available to population to give orientations about psychoactive substances, are both little utilized (Table III).

\section{Other information sources}

The pharmacist of $40.2 \%$ (156) of establishments utilized other information sources about medicines, such as magazines, articles, material from industries and distributors, other healthcare professionals, products package insert, continued education programs and materials distributed during the academic formation.

\section{Information search limiting factors and needs}

The lack of time was considered as the main limitation in the information search. The non-acquaintance about sources availability and the cost of publications were also mentioned as important limiting factors (Table IV). Access in their respective establishments to information sources and activities of continued education were mentioned as necessities of pharmacists.

TABLE IV - Information search limiting factors

\begin{tabular}{lc}
\hline Limiting factors & $\begin{array}{c}\text { Response as } 1^{\text {st }} \text { option } \\
\mathrm{N}(\%)\end{array}$ \\
\hline $\begin{array}{l}\text { Lack of time } \\
\text { Non-acquaintance about } \\
\text { sources availability }\end{array}$ & $96(24.2)$ \\
$\begin{array}{l}\text { High cost of information } \\
\text { sources }\end{array}$ & $83(21.0)$ \\
$\begin{array}{l}\text { Lack of information sources } \\
\text { Difficulty with language }\end{array}$ & $59(14.9)$ \\
$\begin{array}{l}\text { Difficulty of localized } \\
\text { information application }\end{array}$ & $19(4.8)$ \\
& $10(2.5)$ \\
\hline
\end{tabular}

\section{DISCUSSION}

\section{Books and Internet}

The larger availability of pharmaceutical specialties compendiums was expected, considering the utility of the listings of products commercialized within the country and package inserts compilations. However, although useful, these materials are limited sources presenting information resumed and restricted to those information that were available at the moment of the package insert organization, but not after that point in time. It is worthy to consider that the content of these materials is provided to their editors by the pharmaceutical companies themselves. Barros (2000) developed a comparative study between the information contained at Physicians' Desk Reference (PDR), corresponding to Brazilian DEF, and Drug Information for the Health Care Professional (USP-DI), both from United States, with those presented, for the same products, in the Brazilian compendium. The data analysis has pointed to deficiencies of qualitative and quantitative order in the information available at DEF, reinforcing the idea that pharmaceutical specialties compendiums should not be 
understood as sufficient information source for healthcare professionals.

The results obtained are in accordance with similar studies developed at Southeastern Michigan, in Québec, in Hong Kong, in Galicia and in Switzerland, in which the most mentioned publication was also a pharmaceutical specialties compendium (Poirier, Ascione, 1980; Mailhot, Giacona-Dahl, 1987; Chan, Lee, Critchley, 1996; Loza Garcia et al., 2000; Zehnder et al., 2004). Even though the presence of such references is common, these studies demonstrate that in foreign pharmacies, the access to recommended books (Kier, Malone, Mosdell, 2001) and the search of information by pharmacists are more frequent. In the establishments of Southeastern Michigan, the most found references are the monographs book Drug Facts and Comparisons (89\%), books about pharmacological interactions (62\%) and medical dictionaries (68\%).

The Internet is still little utilized as information source about medications, as it is also described in studies developed in pharmacies placed in Japan, Galicia and Switzerland (Iguchi, 1998; Loza Garcia et al., 2000; Zehnder et al., 2004). The Internet utilization is conditioned by factors such as absence of computer, difficulty of access the Web from the establishment, lack of ability in the handling of this resource, non-acquaintance about the websites availability and lack of adequate homepages to professional necessities.

The frequent utilization of search websites emphasizes the importance of a good notion about the selection criteria and critical analysis of information. Respecting to quality of information available at homepages of pharmaceutical distributors and industries, it should be considered a possible tendentious character. As the information from pharmaceutical industry exerts considerable influence on prescription (Tsai, 2003), it is plausible to suppose that dispensation is also influenced. The recommendation is that these websites should be reserved for consultations referring to products identification and their availability in the market; and complementary sources, not linked to industry, should be utilized for other purposes, such as drugs' efficacy, safety, indications, and etc. The homepages of official organs, such as World Health Organization (WHO), Pan American Health Organization (PAHO) and Ministry of Health (Ministério da Saúde - MS), are scarcely utilized.

The Internet allows easy and rapid access to, generally, updated information. The quantity of electronic publications has grown and, currently, there are websites containing information safe and necessary for the pharmaceutical practice (Kier, Malone, Mosdell, 2001) (Picture I).

\section{PICTURE I - Examples of recommended websites}

Bulletins - www.australianprescriber.com

Medscape - www.medscape.com

Ministry of Health - National Therapeutic Formulary -http:// www.opas.org.br/medicamentos/site/uploadArq/FNT_Internet Links_01.pdf

Pan American Health Organization - www.opas.org.br

World Health Organization - www.who.int

Given the nature and the low complexity of the most searched themes in books and Internet, it is supposed that these issues could be satisfactorily answered from just a few, but qualified, information sources.

\section{Information services}

The results demonstrate that there is no ample diffusion, in the pharmaceutical environment, of the access and utility of professional interest information services. Considering the lack of information resources in the establishments, and that consultation to these services is free of charge, it was expected a higher proportion of users.

The access to these mentioned services is an efficient alternative to promote the pharmacist qualification for the performed activities; therefore, there should be a larger divulgence. The utilization of these services provides the assistance by trained professionals; however, it could represent the inconvenience of a delay in decision taking. Although the mentioned services represent an alternative; it is still advisable that the establishment counts on other local references, for resolution of frequent and urgent doubts.

\section{Other information sources}

The predominant utilization of tertiary sources is consonant with results obtained by other investigators (Loza Garcia et al., 2004; Zehnder et al., 2004) and reflects the strategy recommended by experts in the flow of information search. The less frequent use of primary sources could be an indicative that almost all necessary information presents a low complexity level or is answered by tertiary sources. It could even indicate unfamiliarity or difficulty of access to primary information, considering the deficient formation of pharmacists in this aspect.

\section{Information search limiting factors and needs}

The referred lack of time could be attributed to work demand as well as managerial and bureaucratic functions accumulation. This shows the necessity of discussion 
about the tasks redefinition, in a way to allow the development of pharmaceutical activities, such as orientation to patient respecting the use of medicines.

The lack of information sources could be justified by the ignorance about their availability. The high cost involving the acquisition of references constitutes an aggravating factor. It is important to remember that there is a lack of adequate medicine information sources produced in Brazil. Considering the cost of foreign publications and the prevailing languages difficulty in Brazil, a larger production of qualified sources in the country could be an alternative to ease the access to information.

\section{CONCLUSION}

The study demonstrates that the pharmacist acting in these establishments is destitute of adequate information sources. The accessed literature is, in its majority, provided by pharmaceutical industry and the access to independent information is rare. This study results suggest, even, ignorance about the availability and potential of information services of interest to pharmacist.

The availability of information and the pharmacist habilitation to critically utilize it are actual necessities. This study could perhaps contribute for the insertion in the higher education, of contents approaching the critical evaluation and utilization of information about medicines. It could also be useful to help the CIM, and other capable institutions, in the organization of continued education activities and in the elaboration of information sources, specifically addressed to pharmacists acting in drugstores and pharmacies. The developed diagnosis could even be utilized to quantify the impact of possible interventions with educative measures.

From the point of view of the topics evaluated in this work, the drugstores and pharmacies in the Metropolitan Region of Porto Alegre and, probably, in the country, as they are currently established, present difficulties to provide an appropriate pharmaceutical service to community. The professional improvement in the ambit of these establishments could contribute for the qualification of pharmacist professionals and for the implantation of Pharmaceutical Care programs, aiming to achieve the rational use of medicines.

\section{ACKNOWLEDGMENT}

To National Council of Scientific and Technological Development (Conselho Nacional de Desenvolvimento Cientifico e Tecnológico - CNPq) and to Foundation of Support to Research of Rio Grande do Sul (Fundação de
Amparo à Pesquisa do Rio Grande do Sul-FAPERGS).

\section{REFERENCES}

AMERSON, A.B.; GORA-HARPER, M.L. Introduction to the concept of medication information. In: MALONE, P.M.; MOSDELL, K.W.; KIER, K.L.; STANOVICH, J.E., Eds., Drug information: a guide for pharmacists. New York: McGraw-Hill, 2001. p. 1-18.

BARROS, J.A.C. A (Des)informação sobre medicamentos: o duplo padrão de conduta das empresas farmacêuticas. $\mathrm{Cad}$. Saúde Pública, v.16, n.2, p.421-427, 2000.

BRASIL. Ministério da Saúde. Lei n ${ }^{\circ}$ 5991, de 17 de dezembro de 1973. Dispõe sobre o controle sanitário do comércio de drogas, medicamentos, insumos farmacêuticos e correlatos, e dá outras providências. Available at: $<\mathrm{http}: / / \mathrm{www}$.anvisa. gov.br>. Accessed on: 23 out. 2008.

CHAN, T.Y.; LEE, K.K.; CRITCHLEY, J.A. The needs and sources of drug information among pharmacists in Hong Kong. J. Clin. Pharm. Ther., v.21, n.5, p.325-330, 1996.

IGUCHI, S.; OHNISHI, M.; NISHIYAMA, T.; HOSONO, K.; UMEZAWA, C. Community pharmacy practice in Japan - results of a survey. J. Clin. Pharm. Ther., v.23, n.3, p.223-227, 1998.

IVAMA, A.M.; NOBLAT, L.; CASTRO, M.S.; OLIVEIRA, N.V.B.V.; JARAMILLO, N.M.; RECH, N. Consenso brasileiro de atenção farmacêutica: Proposta. Brasília: OPAS, 2002. $24 \mathrm{p}$.

KIER, K.L.; MALONE, P.M.; MOSDELL, K.W. Drug information resources. In: MALONE PM, MOSDELL KW, KIER KL, STANOVICH JE. Drug information: a guide for pharmacists. New York: McGraw-Hill, 2001. p.53-94.

LOZA GARCÍA, M.I.; CORDERO PUENTES, L.; FERNÁNDES-LLIMÓS SOMOZA, F.; GARCÍA CORRAL, P.; CADAVID TORRES, M.I.; SANZ I CARRERAS, F.; CALLEJA SUÁREZ, J.M. Fuentes de información sobre medicamentos utilizadas por los farmacéuticos comunitarios de Galicia. Pharm. Care Esp., v. 2, n.22, p.108-122, 2000.

MAILHOT, C.; GIACONA-DAHL, N.S. Drug Information Services in Quebec: determination of community and hospital pharmacists' needs. Drug Intell. Clin. Phar., v.21, n.1, p.57-63, 1987. 
MÜLLEROVÁ, H.; VLCEK, J. European drug information centers - survey of activities. Pharm. World Sci., v.20, n.3, p.131-135, 1998.

MARIN N, LUIZA VL, OSORIO-DE-CASTRO CGS, MACHADO-DOS-SANTOS S (Orgs.). Assistência farmacêutica para gerentes municipais. Rio de Janeiro: OPAS/OMS, 2003. p.287-334.

METROPLAN - Fundação Estadual de Planejamento Metropolitano e Regional. Available at: <http://www. metroplan.rs.gov.br>. Accessed on: 23 oct. 2008 .

OPAS. Centros de información de medicamentos: una estrategia de apoyo al uso racional de medicamentos. Santo Domingo: Informe de Grupo de Trabajo Regional, 1995. 32 p.

POIRIER, T.I.; ASCIONE, F.J. Printed drug information sources used by pharmacists in southeastern Michigan. AJHP, v.37, n.5, p.687-689, 1980.
ROSENBERG, J.M.; KOUMIS, T.; NATHAN, J.P.; CICERO, L.A.; MCGUIRE, H. Current status of pharmacist-operated drug information centers in the United States. AJHP, v.61, n.19, p.2023-2032, 2004.

TSAI, A.C. Policies to regulate gifts to physicians from industry. JAMA, v.290, n.13, p.1776, 2003.

VIDOTTI, C.C.F. Drug Information Centers in developing countries and the promotion of rational use of drugs: a viewpoint about challenges and perspectives. Int. Pharm. J., v.18, n.1, p.21-23, 2004.

ZEHNDER, S.; BEUTLER, M.; BRUPPACHER, R.; EHRENHÖFER, T.; HERSBERGER, K.E. Needs and use of drug information sources in community pharmacies: a questionnaire based survey in German-speaking Switzerland. Pharm. World Sci., v.26, n.4, p.197-202, 2004.

Received for publication on $25^{\text {th }}$ july 2008 Accepted for publication on $16^{\text {th }}$ november 2008 